\title{
Moss-cyanobacteria associations as biogenic sources of nitrogen in boreal forest ecosystems
}

\author{
Kathrin Rousk ${ }^{1 *}$, Davey L. Jones ${ }^{1}$ and Thomas H. DeLuca ${ }^{2}$ \\ 1 School of Environment, Natural Resources and Geography, Bangor University, Bangor, Gwynedd, UK \\ 2 School of Environment and Forest Sciences, University of Washington, Seattle, WA, USA
}

\section{Edited by:}

Per Bengtson, Lund University, Sweden

Reviewed by:

Marja A. Tiirola, University of

Jyväskylä, Finland

Richard S. Winder, Natural

Resources Canada, Canada

*Correspondence:

Kathrin Rousk, School of

Environment, Natural Resources and

Geography, Bangor University,

Deiniol Road, Bangor, Gwynedd

LL 57 2UW, UK

e-mail:kathrin.rousk@gmx.net
The biological fixation of atmospheric nitrogen $(\mathrm{N})$ is a major pathway for available $\mathrm{N}$ entering ecosystems. In N-limited boreal forests, a significant amount of $\mathrm{N}_{2}$ is fixed by cyanobacteria living in association with mosses, contributing up to $50 \%$ to the total $\mathrm{N}$ input. In this review, we synthesize reports on the drivers of $\mathrm{N}_{2}$ fixation in feather moss-cyanobacteria associations to gain a deeper understanding of their role for ecosystem-N-cycling. Nitrogen fixation in moss-cyanobacteria associations is inhibited by $\mathrm{N}$ inputs and therefore, significant fixation occurs only in low $\mathrm{N}$-deposition areas. While it has been shown that artificial $\mathrm{N}$ additions in the laboratory as well as in the field inhibit $\mathrm{N}_{2}$ fixation in moss-cyanobacteria associations, the type, as well as the amounts of $\mathrm{N}$ that enters the system, affect $\mathrm{N}_{2}$ fixation differently. Another major driver of $\mathrm{N}_{2}$ fixation is the moisture status of the cyanobacteria-hosting moss, wherein moist conditions promote $\mathrm{N}_{2}$ fixation. Mosses experience large fluctuations in their hydrological status, undergoing significant natural drying and rewetting cycles over the course of only a few hours, especially in summer, which likely compromises the $\mathrm{N}$ input to the system via $\mathrm{N}_{2}$ fixation. Perhaps the most central question, however, that remains unanswered is the fate of the fixed $\mathrm{N}_{2}$ in mosses. The cyanobacteria are likely to leak $\mathrm{N}$, but whether this $\mathrm{N}$ is transferred to the soil and if so, at which rates and timescales, is unknown. Despite our increasing understanding of the drivers of $\mathrm{N}_{2}$ fixation, the role moss-cyanobacteria associations play in ecosystem-N-cycling remains unresolved. Further, the relationship mosses and cyanobacteria share is unknown to date and warrants further investigation.

Keywords: acetylene reduction, boreal biome, bryophytes, global change, N-cycle, nitrogenase, symbioses

\section{THE N-CYCLE IN BOREAL FORESTS}

Nitrogen $(\mathrm{N})$ is the limiting nutrient for productivity in boreal forests (Tamm, 1991) due to limited $\mathrm{N}$ introduction and the accumulation of carbon (C)-rich recalcitrant litter and plant material, which leads to rapid immobilization of inorganic $\mathrm{N}$ and decreased net N mineralization rates (Keeney, 1980; Scott and Binkley, 1997). Therefore, boreal forest soils are characterized by a tight internal $\mathrm{N}$-cycle where immobilization processes dominate (Giesler et al., 1998; Schimel and Bennett, 2004). Considering that the boreal biome accounts for 17\% of the Earth's land surface (DeLuca and Boisvenue, 2012), the ability of this ecosystem to sustain productivity is important to consider for global biogeochemical budgets.

One main source of biological available $\mathrm{N}$ is the fixation of atmospheric $\mathrm{N}_{2}$ performed by free-living and symbiotic bacteria (Vitousek et al., 1997; Reed et al., 2011). This conversion of $\mathrm{N}_{2}$ to ammonia $\left(\mathrm{NH}_{3}\right)$ is the initial step in the N-cycle. Nitrogen-fixing cyanobacteria have been found to colonize a range of moss species in pristine, unpolluted environments (Basilier and Granhall, 1978; DeLuca et al., 2002; Sorensen et al., 2006; Ininbergs et al., 2011), where the $\mathrm{N}_{2}$ fixation of mosscyanobacteria associations contribute $>2 \mathrm{~kg} \mathrm{~N} \mathrm{ha}^{-1} \mathrm{yr}^{-1}$ to the total N input in these systems (DeLuca et al., 2002; Gundale et al., 2011; Sorensen and Michelsen, 2011). These moss-cyanobacteria associations contribute significantly to the $\mathrm{N}$-input in boreal forests (Figure 1) by accumulating $\mathrm{N}$ in the moss tissue, which becomes available upon disturbances like drying-rewetting -and fire events (Carleton and Read, 1991; Wilson and Coxson, 1999) as well as via slow mineralization (Hobbie, 1996) and mycorrhizal associations (Kauserud et al., 2008; Davey et al., 2009). Thus, moss-cyanobacteria associations represent a vital feature for maintaining productivity in boreal ecosystems.

\section{BOREAL FORESTS, MOSSES, AND CYANOBACTERIA}

Boreal forests receive low amounts of background N-deposition (Phil-Karlsson et al., 2009). In addition, boreal forest soils are characterized by low concentrations of inorganic $\mathrm{N}$, low $\mathrm{pH}$ and low temperatures (Read, 1991), contributing to the $\mathrm{N}$-limitation in these systems. Mosses likely play a crucial role in boreal forest ecosystems due to their contribution to habitat heterogeneity (Longton, 1988), their influence on hydrology, temperature, and chemistry of boreal forest soils (Cornelissen et al., 2007). For instance, summer soil temperatures below moss carpets are lower compared to sites without moss cover (Bonan, 1991; Startsev et al., 2007), leading to slower decomposition rates below mosses (Prescott et al., 1993). However, mosses release substantial amounts of nutrients $[\mathrm{C}, \mathrm{N}$, phosphorus $(\mathrm{P})]$ upon rewetting of dried tissue, funneling plant and 


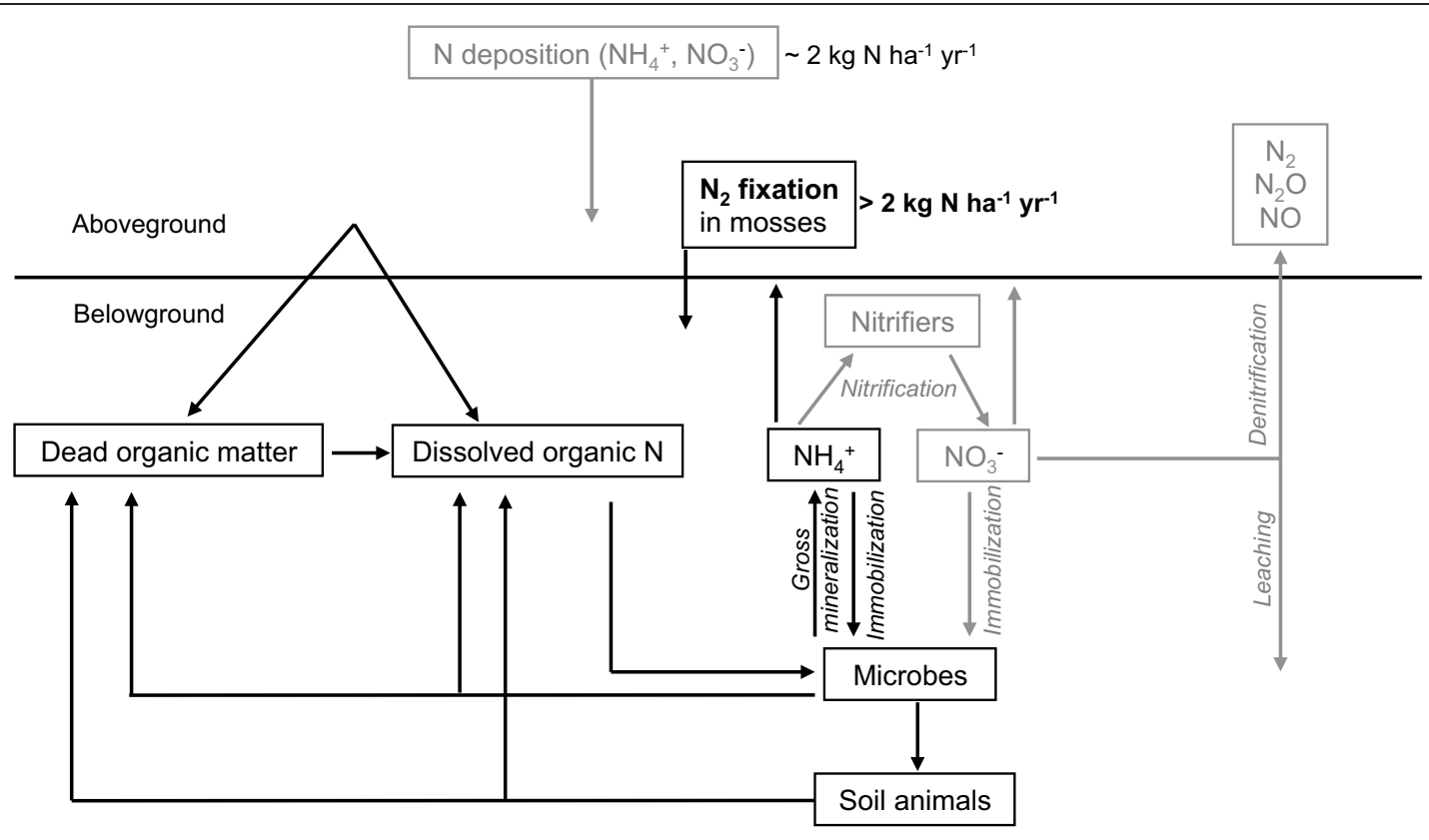

FIGURE 1 | A simplified overview of the $\mathrm{N}$-cycle in boreal forests, including $\mathrm{N}_{2}$ fixation in moss carpets as a candidate for filling the $\mathrm{N}$-gap in boreal ecosystems. Boxes and arrows in gray indicate less common or less important pathways and sources of $\mathrm{N}$ in the boreal forest.

microbial-available nutrients into the soil (Carleton and Read, 1991; Wilson and Coxson, 1999). Further, mosses contribute fundamentally to the biomass and productivity in boreal forests, and may exceed tree biomass [e.g., $120 \mathrm{~g} \mathrm{~m}^{-2} \mathrm{yr}^{-1}$ for feather mosses vs. $102 \mathrm{gm}^{-2} \mathrm{yr}^{-1}$ for black spruce, (Van Cleve et al., 1983)] (see also Martin and Adamson, 2001; Turetsky, 2003; Lindo and Gonzalez, 2010). For instance, the ubiquitous feather moss Pleurozium schreberi (Brid.) Mitt. accounts for $70-100 \%$ of the ground cover in boreal forests (Oechel and Van Cleve, 1986; DeLuca et al., 2002; Zackrisson et al., 2004; Street et al., 2013) (Figure 2A).

By buffering abiotic factors (e.g., temperature, wind) and exhibiting a high water retention capacity (Dickson, 2000), mosses can provide a stable and favorable habitat for cyanobacterial colonizers, promoting $\mathrm{N}_{2}$ fixation in $\mathrm{N}$-limited ecosystems (DeLuca et al., 2002). The association between mosses and cyanobacteria (Figure 2B) could play a fundamental role for the $\mathrm{N}$-cycle in $\mathrm{N}$-limited boreal forests by contributing $>2 \mathrm{~kg} \mathrm{~N} \mathrm{ha}^{-1}$ $\mathrm{yr}^{-1}$ via $\mathrm{N}_{2}$ fixation to the $\mathrm{N}$-pool in mature forest ecosystems (DeLuca et al., 2002). This value is on par with the magnitude of atmospheric $\mathrm{N}$-deposition in the boreal biome, which ranges between 1 and $2 \mathrm{~kg} \mathrm{~N} \mathrm{ha}^{-1} \mathrm{yr}^{-1}$ (e.g., Gundale et al., 2011).

To date, several genera of cyanobacteria (Nostoc, Stigonema, Calothrix, Cylindrospermum) have been identified living epiphytically on feather mosses like P. schreberi and Hylocomium splendens (Hedw.) (Gentili et al., 2005; Ininbergs et al., 2011). Numbers of cyanobacterial cells and $\mathrm{N}_{2}$ fixation rates in feather mosses follow a linear relationship (DeLuca et al., 2007), indicating that cyanobacteria are responsible for $\mathrm{N}_{2}$ fixation, whereas the contribution of methanotrophs to $\mathrm{N}_{2}$ fixation in feather mosses might be negligible (Leppänen et al., 2013).

\section{ABIOTIC CONTROLS OF $N_{2}$ FIXATION IN MOSS-CYANOBACTERIA ASSOCIATIONS NITROGEN}

Moss biomass (Solga et al., 2005; Nordin et al., 2006) and biomass and activity (nitrogenase enzyme) of cyanobacteria (DeLuca et al., 2007, 2008; Sorensen et al., 2012) are sensitive to $\mathrm{N}$ inputs (Table 1), leading to drastic reductions in the abundance of dominant moss species and to significant reductions or total exclusion of $\mathrm{N}_{2}$ fixation in moss-cyanobacteria associations (Zackrisson et al., 2004; DeLuca et al., 2008; Gundale et al., 2011; Ackermann et al., 2012). The amount of $\mathrm{N}$ input dictates in which form $\mathrm{N}$ enters the ecosystem: either as organic $\mathrm{N}$ via the moss layer when $\mathrm{N}$ deposition is low $\left(<3 \mathrm{~kg} \mathrm{~N} \mathrm{ha}^{-1} \mathrm{yr}^{-1}\right)$ and $\mathrm{N}_{2}$ fixation is high or as inorganic $\mathrm{N}$ when $\mathrm{N}$ deposition is higher and bypasses the moss layer. Mosses effectively absorb nutrients and water from atmospheric deposition, making them extremely sensitive to increased nutrient inputs (e.g., Bengtsson et al., 1982). For instance, Ackermann et al. (2012) showed that $\mathrm{N}_{2}$ fixation in moss-cyanobacteria associations along road-derived $\mathrm{N}$-deposition gradients in Northern Sweden was significantly inhibited close to busy roads. While other measured factors (soil$\mathrm{N}$, -C concentrations, microbial PLFAs, heavy metals in moss tissue) did not change along the road-gradients, $\mathrm{N}_{2}$ fixation increased with increasing distance to the busy roads, suggesting that $\mathrm{N}_{2}$ fixation in feather mosses is a sensitive indicator for N-deposition (Ackermann et al., 2012). Artificial N additions in-situ have been shown to significantly decrease numbers of cyanobacterial cells on moss leaves at levels of only $3 \mathrm{~kg} \mathrm{~N}$ $\mathrm{ha}^{-1} \mathrm{yr}^{-1}$ coinciding with a significant reduction in $\mathrm{N}_{2}$ fixation in moss-cyanobacteria associations (Gundale et al., 2011). However, additions of $10 \mathrm{~kg} \mathrm{~N} \mathrm{ha}^{-1}$ in laboratory experiments did 


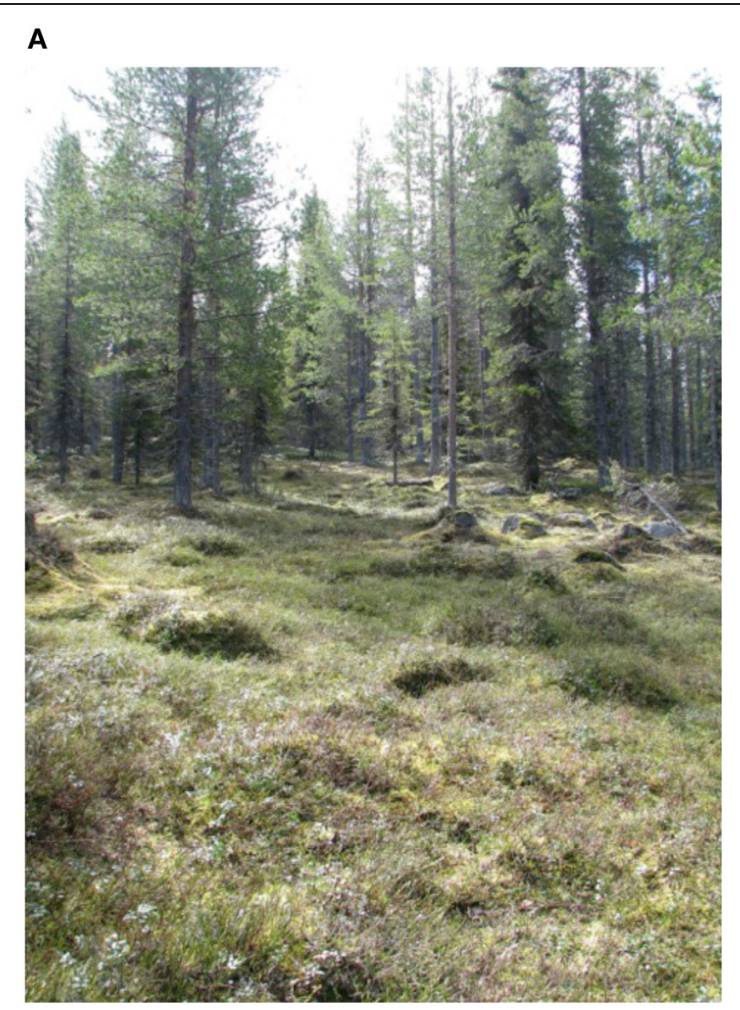

B

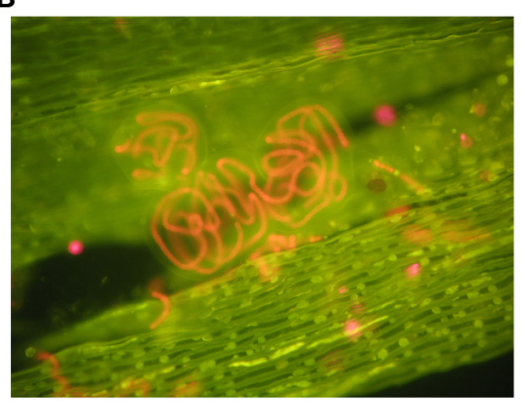

FIGURE 2 | (A) A late-succession boreal forest site in Northern Sweden with an open canopy and a moss-dominated understory. Mosses, in particular feather mosses like Pleurozium schreberi and Hylocomium splendens, cover $70-100 \%$ of the ground in boreal forests. Photo by K. Rousk. (B) A section of a Pleurozium schreberi-leaf at $\times 100$ magnification under an UV-fluorescence microscope. Coiled chains of Nostoc spp. are seen in bright red. The moss-cyanobacteria association is assumed to be mutualistic, however, no attempts have been made so far to identify the relationship moss and cyanobacteria share. Photo by K. Rousk.

not inhibit $\mathrm{N}_{2}$ fixation in mosses (Ackermann, 2013), suggesting that the mosses likely experience higher $\mathrm{N}$ loads in the field than expected. When combining values of atmospheric $\mathrm{N}$-deposition (1-2 kg N ha ${ }^{-1} \mathrm{yr}^{-1}$ ) (Phil-Karlsson et al., 2009; Gundale et al., 2011) with values of $\mathrm{N}$ throughfall (>8 $\mathrm{kg} \mathrm{N} \mathrm{ha}^{-1} \mathrm{yr}^{-1}$ ) (Rousk et al., 2013a) in boreal forests, $\mathrm{N}$ input will easily reach values higher than $10 \mathrm{~kg} \mathrm{~N} \mathrm{ha}^{-1}$. Further, mosses collected from a high $\mathrm{N}$-deposition area in Wales $\left(12-15 \mathrm{~kg} \mathrm{~N}^{-1} \mathrm{yr}^{-1}\right.$ ) were shown to start fixing $\mathrm{N}_{2}$ after a period of $\mathrm{N}$ deprivation (Ackermann, 2013).

\section{PHOSPHORUS}

In contrast to $\mathrm{N}$ additions that would likely only decrease $\mathrm{N}_{2}$ fixation rates, nutrient additions (other than $\mathrm{N}$ ) to moss carpets have the potential to increase $\mathrm{N}_{2}$ fixation rates. The addition of soluble $\mathrm{P}$ to Arctic mosses has been reported to increase $\mathrm{N}_{2}$ fixation rates (Chapin et al., 1991). Studies in boreal forest ecosystems have been conducted both on late succession forest stands that had high rates of $\mathrm{N}_{2}$ fixation and on early succession stands that had low rates of $\mathrm{N}_{2}$ fixation (Zackrisson et al., 2004). Phosphorus additions ( 0 and $5 \mathrm{~kg} \mathrm{P} \mathrm{ha}^{-1}$ as $\mathrm{NaH}_{2} \mathrm{PO}_{4}$ ) to field plots resulted in a slight increase in $\mathrm{N}_{2}$ fixation rates in late succession plots just 8 weeks after the original application of $\mathrm{P}$ (Zackrisson et al., 2004), but a more prominent effect was recorded 1 year after the original treatment in the late and a significant effect in the early succession site (see Figure 3). Five years after the $\mathrm{P}$ additions, the positive effects were less pronounced and again, only significant in the early succession site (Figure 3). Phosphorus additions with and without $\mathrm{N}$ additions to plots of $H$. splendens showed little direct response to $\mathrm{P}$ additions of $5 \mathrm{~kg} \mathrm{P} \mathrm{ha}^{-1}$, but also demonstrated this species to be more tolerant to $\mathrm{N}$ deposition and to respond somewhat to $\mathrm{P}$ additions in the presence of added $\mathrm{N}$ (Zackrisson et al., 2009).

There have also been reports of $\mathrm{P}$ suppression of $\mathrm{N}_{2}$ fixation in Subantarctic epiphytic cyanobacteria (Smith, 1984), however, the findings by Chapin et al. (1991) and Zackrisson et al. (2009) suggest a positive effect of $\mathrm{P}$ additions on $\mathrm{N}_{2}$ fixation in mosses. Nevertheless, reported results on the effects of $\mathrm{P}$ additions are ambiguous and the outcome of P-fertilizations seems to be dependent on the availability of $\mathrm{P}$ and other nutrients. Studies on asymbiotic $\mathrm{N}_{2}$ fixation in tropical rainforests suggest that $\mathrm{N}_{2}$ fixation can be limited by $\mathrm{P}$ (Vitousek and Hobbie, 2000; Reed et al., 2013), molybdenum (Mo) (Barron et al., 2009), or by $\mathrm{P}$ and Mo in combination (Reed et al., 2013), depending on the availability of $\mathrm{P}$ and Mo in the sites studied (Wurzburger et al., 2012).

\section{MOISTURE, TEMPERATURE, AND LIGHT}

Besides the availability of $\mathrm{N}$ and $\mathrm{P}$, other abiotic factors dramatically affect $\mathrm{N}_{2}$ fixation in moss-cyanobacteria associations. For instance, the hydrological status of the moss seems to be a crucial factor driving $\mathrm{N}_{2}$ fixation. Moisture, as well as frequent rainfall promotes $\mathrm{N}_{2}$ fixation rates in mosses (Gundale et al., 2009, 2012a,b; Jackson et al., 2011; Jean et al., 2012). This is not surprising, given the fact that mosses absorb water over their entire surface from the atmosphere and do not take up water from the soil (Tyler, 1990). Therefore, mosses readily lose water under dry conditions, which could in turn affect the activity of cyanobacterial associates. Moss growth, as well as cyanobacterial activity, peak in early spring after snowmelt (May-June) and in late summer (September), and drop in between (July-August) (Basilier and Granhall, 1978; Zackrisson et al., 2004). This reduction in moss growth and activity in summer could correspond to a period of dormancy in mosses as a result of dry conditions or photoinhibition (Sveinbjörnsson and Oechel, 1992; Zackrisson et al., 2004). In the boreal forest, mosses can be exposed to extreme daily fluctuations in moisture and temperature conditions. Frequently, dry episodes are followed by heavy rainfall over the course of only few hours. Thus, mosses experience natural and 
Table 1 | Effects of selected abiotic factors on $\mathrm{N}_{2}$ fixation in different moss species from boreal and arctic environments.

\begin{tabular}{|c|c|c|c|}
\hline Moss species & Abiotic factor & Effect on $\mathrm{N}_{2}$ fixation & References \\
\hline Sphagnum riparium & Temperature & + up to $15^{\circ} \mathrm{C} ; \mathrm{T}_{\text {opt }} 16^{\circ} \mathrm{C}$ & Basilier and Granhall, 1978 \\
\hline Brachythecium subplicatum & Temperature & + up to $25^{\circ} \mathrm{C} ; \mathrm{T}_{\text {opt }} 25-27^{\circ} \mathrm{C}$ & Smith, 1984 \\
\hline Pleurozium schreberi-Nostoc-associate & Temperature & $\mathrm{T}_{\max } 13^{\circ} \mathrm{C}$ & Gentili et al., 2005 \\
\hline Pleurozium schreberi-Calothrix -associate & Temperature & $\mathrm{T}_{\max } 30^{\circ} \mathrm{C}$ & Gentili et al., 2005 \\
\hline Pleurozium schreberi & Temperature & $+\mathrm{T}_{o p t} 25^{\circ} \mathrm{C}$ & Gundale et al., 2012a \\
\hline Hylocomium splendens & Temperature & - & Gundale et al., 2012a \\
\hline Hylocomium splendens & Temperature & No effect & Sorensen et al., 2012 \\
\hline Aulacomnium turgidum & Temperature & - & Sorensen et al., 2012 \\
\hline Pleurozium schreberi & N-addition & $-\left(4.25 ; 25.5 \mathrm{~kg} \mathrm{~N} \mathrm{ha}^{-1} \mathrm{yr}^{-1}\right)$ & Zackrisson et al., 2004 \\
\hline Pleurozium schreberi & N-addition & $-\left(3 ; 6 ; 12 ; 50 \mathrm{~kg} \mathrm{~N} \mathrm{ha}^{-1} \mathrm{yr}^{-1}\right)$ & Gundale et al., 2011 \\
\hline Hylocomium splendens & N-addition & $-\left(100 \mathrm{~kg} \mathrm{~N} \mathrm{ha}^{-1} \mathrm{yr}^{-1}\right)$ & Sorensen et al., 2012 \\
\hline Aulacomnium turgidum & N-addition & $-\left(100 \mathrm{~kg} \mathrm{~N} \mathrm{ha}^{-1} \mathrm{yr}^{-1}\right)$ & Sorensen et al., 2012 \\
\hline Brachythecium subplicatum & Moisture & + & Smith, 1984 \\
\hline Pleurozium schreberi & Water addition & + & Gundale et al., 2009 \\
\hline Pleurozium schreberi & Water addition & + & Gundale et al., 2012b \\
\hline Pleurozium schreberi & P-addition & + & Zackrisson et al., 2004 \\
\hline Hylocomium splendens & P-addition & No effect & Zackrisson et al., 2009 \\
\hline Sphagnum riparium & P-addition & + & Basilier and Granhall, 1978 \\
\hline Brachythecium subplicatum & P-addition & - & Smith, 1984 \\
\hline
\end{tabular}

P, Phosphorus; N, Nitrogen; Topt, optimum temperature; $T_{\max }$ maximum temperature; positive, + ; negative, - ; or no effects are given.
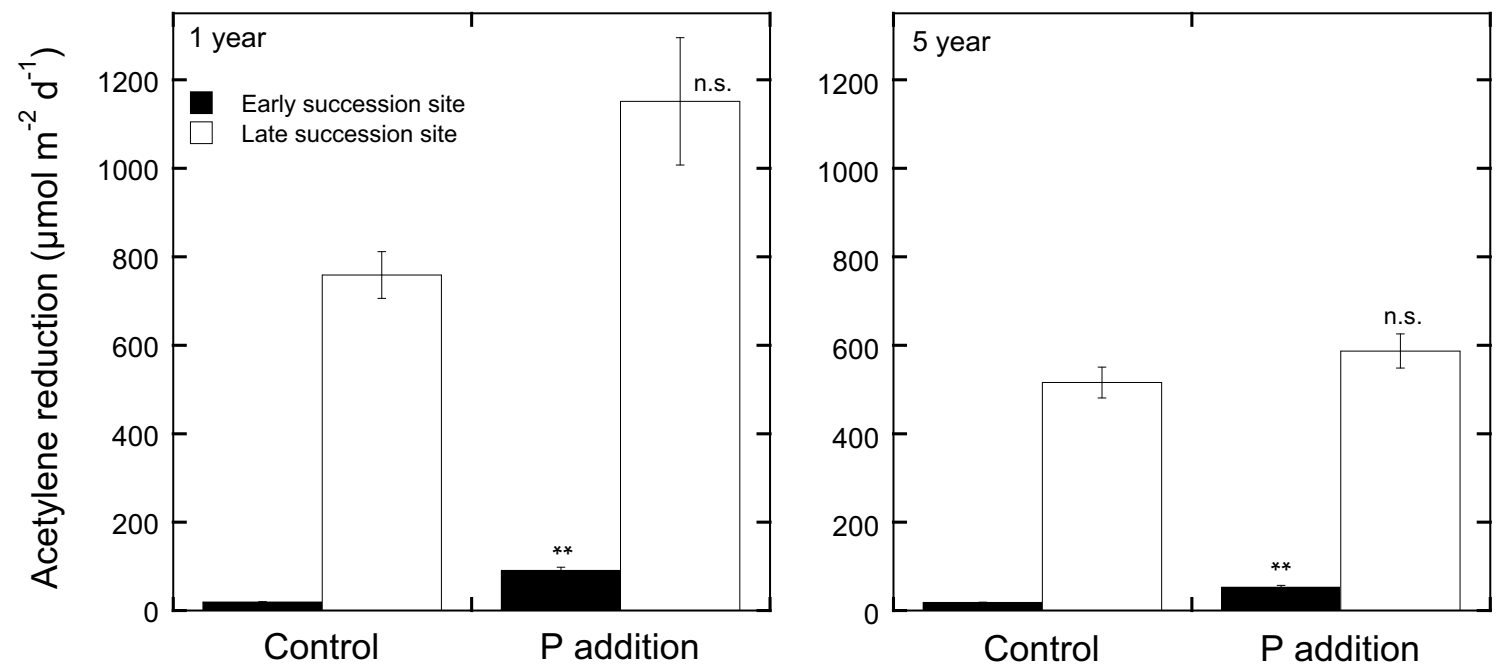

FIGURE 3 | Acetylene reduction rates $\left(\mu \mathrm{mol} \mathrm{m}^{-2} \mathrm{~d}^{-1}\right)$ in Pleurozium schreberi at one late (open bars) and one early (filled bars) succession forest site in northern Sweden in response to $P$ additions $\left(5 \mathrm{~kg} \mathrm{P}^{\mathrm{P}} \mathrm{ha}^{-1}\right.$ $\mathbf{y r}^{-1}$ as $\mathbf{N a H}_{2} \mathbf{P O}_{4}$ ). Shown are acetylene reduction rates measured 1 and 5 years after the $\mathrm{P}$ additions. Phosphorus was applied annually to 10 replicate
$1.0 \mathrm{~m}^{2}$ plots in four doses over the course of the summer. Distilled water was applied to the control plots. Mean values $(n=10)$ and +1 SE are given, ** represents significant at $P<0.05$ and n.s. represents not significant as determined by a One-Way ANOVA. Experimental design, sampling, and data analyses are reported for year-one in Zackrisson et al. (2004). intensive recurrent drying and rewetting events. Significant leaching of nutrients from mosses has been found upon rewetting of dried moss (Carleton and Read, 1991; Wilson and Coxson, 1999), resulting in nutrient-rich leachates available for soil biota. Mosses are relatively desiccation-tolerant; they are able to withstand drying until no free water remains in the cells and quickly return to normal metabolism and growth upon rewetting (Proctor, 2001).
Also, many fundamental processes like photosynthesis resume quickly after rewetting, with some moss species starting to fix $\mathrm{CO}_{2}$ within minutes upon rewetting (Proctor et al., 2007). However, the moisture condition of the moss could change the nutrient supply and exchange between moss and associated cyanobacteria. Scott (1960) suggested that not only nutrients, but also light and moisture could affect the balance and rates of nutrients exchanged 
between the symbiotic partners in lichen symbioses, upsetting the relationship between them.

The recovery of nitrogenase activity in free-living cyanobacteria after desiccation is supposed to be slower than the recovery of photosynthesis because de novo protein synthesis is required for $\mathrm{N}_{2}$ fixation ( $>24 \mathrm{~h}$ vs. $4 \mathrm{~h}$ for $\mathrm{N}_{2}$ fixation and photosynthesis, respectively) (Hawes et al., 1992). Cyanobacteria can form dormant cells during dry conditions and resuscitate upon rewetting to resume fixing $\mathrm{N}_{2}$ (Kaplan-Levy et al., 2010). However, recovery of $\mathrm{N}_{2}$ fixation in the moss-cyanobacteria association after rewetting of dried moss has been shown to be very slow. It took 5 days for $\mathrm{N}_{2}$ fixation to reach values comparable to moist moss after rewetting of air-dried moss (Ackermann, 2013). In contrast, other processes like photosynthesis have been reported to recover much faster than $\mathrm{N}_{2}$ fixation upon rewetting in free-living cyanobacteria (Hawes et al., 1992; Belnap, 2001). This lag-time between rewetting and $\mathrm{N}_{2}$ fixation activity in cyanobacteria is likely the result of de novo synthesis of proteins for $\mathrm{N}_{2}$ fixation, and the need for differentiation of vegetative cells to heterocysts, in which the reduction of $\mathrm{N}_{2}$ takes place (Belnap, 2001). Thus, $\mathrm{N}$ input via $\mathrm{N}_{2}$ fixation could be compromised in summer months when the moss is desiccated. In addition, predicted increases in temperatures and more extreme weather events in the next century (IPCC, 2007) could fundamentally affect the $\mathrm{N}_{2}$ fixation capacity in moss-cyanobacteria associations.

Reports on the temperature relationship of $\mathrm{N}_{2}$ fixation in moss-cyanobacteria associations are varied (Table 1), ranging from temperature optima at $16^{\circ} \mathrm{C}$ (Basilier and Granhall, 1978) to $22-27^{\circ} \mathrm{C}$ (Smith, 1984; Gundale et al., 2012a) and depending on light conditions, moss species and the associated species of cyanobacteria (Smith, 1984; Gentili et al., 2005; Gundale et al., 2012a; Jean et al., 2012; Sorensen et al., 2012). The varying reports on the temperature effects on $\mathrm{N}_{2}$ fixation call for further studies.

Nitrogen fixation is a metabolically costly process (Turetsky, 2003; Houlton et al., 2008; Reed et al., 2011). In autotrophic $\mathrm{N}_{2}$-fixers, this high energy demand can be met via the products of photosynthesis (Belnap, 2001), which is dependent on light conditions. The effects of light intensities on $\mathrm{N}_{2}$ fixation in moss-cyanobacteria associations have rarely been studied. There are indications that $\mathrm{N}_{2}$ fixation in mosses decreases at high light intensities (500-900 $\mu \mathrm{mol} \mathrm{m}^{-2} \mathrm{~s}^{-1}$ ) (Smith, 1984; Gundale et al., 2012a). However, the effects of light, moisture and temperature on processes like $\mathrm{N}_{2}$ fixation are tightly coupled (Gundale et al., 2012a,b), making the identification of the most influencing driver difficult.

\section{THE ECOLOGY OF MOSS-CYANOBACTERIA ASSOCIATIONS-WHAT RELATION DO THEY SHARE?}

The term symbiosis (Symbiotismus) was first introduced in 1877 by Frank, who described it as a case in which two different species (symbionts) live in or on one another, irrespective of the role of the individuals. Cyanobacteria are an ancient, diverse and widespread group found as free-living cells and colonies as well as living in symbiosis and associations with higher plants, lichens and bryophytes (Rai et al., 2000; Adams and Duggan, 2008; Meeks, 2009). Cyanobacteria are facultative autotrophs, they possess the ability to fix $\mathrm{C}$ as well as $\mathrm{N}$, which allows the establishment of the cyanobacteria-plant symbioses in ecosystems where these essential nutrients are limiting. In their free-living state, cyanobacteria retain the ability to fix both essential nutrients $(\mathrm{C}, \mathrm{N})$. However, when living in association with a plant partner, cyanobacteria commonly discontinue photosynthesis and instead obtain $\mathrm{C}$ from their symbiotic partner in exchange for fixed $\mathrm{N}_{2}$ (Meeks and Elhai, 2002; Adams and Duggan, 2008; Meeks, 2009). The plant partner receives $\mathrm{N}_{\text {as }} \mathrm{NH}_{4}^{+}$or amino acids from the cyanobacteria and in return provides carbohydrates, shelter and protection (Steinberg and Meeks, 1991). Given that $\mathrm{N}_{2}$ fixation is a highly energy demanding process (Scherer and Zhong, 1991; Turetsky, 2003; Houlton et al., 2008; Reed et al., 2011), living in association with a symbiotic partner could compensate for energy needs. Although direct evidence is lacking, similar mechanisms and principles are assumed to take place in mosscyanobacteria associations (Rai et al., 2000; Turetsky, 2003): the moss offers protection and carbohydrates while receiving fixed $\mathrm{N}_{2}$ in return. However, in the lichen symbiosis for instance, the balance between the exchange of nutrients seems to be not entirely mutually beneficial, but rather depends on the nutrient demands of the partners (Johansson et al., 2011). Over 50 years ago, Scott (1960) reported that variations in the supply of nutrients, light, and moisture could upset the symbiotic balance between the mycobiont and photobiont in lichen symbioses. The growth of both symbionts is controlled by moisture levels and availability of $\mathrm{N}$ and $\mathrm{C}$, resulting in a delicate balance between the partners (Scott, 1960).

In addition to nutrient exchange, mutual protection between the partners could play a role in the moss-cyanobacteria relationship. Although mosses are a characteristic and dominant feature of boreal forests, they are consumed by very few herbivores (Prins, 1982; Eskelinen, 2002) and decomposition of moss litter is very slow [ $>150$ vs. 30 days for mosses vs. vascular plants, respectively; (Hobbie, 1996)]. Mosses produce inhibitory compounds like phenols and moss-specific secondary metabolites (oxylipins) (Matsui, 2006; Croisier et al., 2010). These inhibitory compounds could be related to the recalcitrant nature of moss litter and the resistance of mosses to decomposition and can repress enzyme activity involved in the breakdown process (Triebwasser et al., 2012). Given the low density of easily decomposable plants in boreal ecosystems, the low litter quality of mosses (Prins, 1982; Hobbie, 1996; Lang et al., 2009) seems to be an insufficient explanation for the lack of decomposition of this plentiful plant material. Cyanobacteria are known to produce toxins (e.g., microcystins) (Cox et al., 2005; Adams and Duggan, 2008; Kaasalainen et al., 2012). Microcystins are highly toxic, small, cyclic peptides produced by cyanobacteria in freshwater systems (predominantly strains of the genus Nostoc) that are reported to be responsible for animal poisoning (Sivonen, 2009). Nostoc has been found to also produce the toxin when living in symbioses with lichens (Kaasalainen et al., 2009, 2012). Reindeer thus avoid eating cyanolichens, even during periods of starvation (Rai et al., 2002; Storeheier et al., 2002). Given that Nostoc colonizes mosses as well, it is possible that toxic substances produced by the cyanobacterial colonizer provide protection and would explain the moss' resistance toward decomposition, which would 
add to the proposed mutualistic relationship between mosses and cyanobacteria. However, the inhibition of soil bacterial growth by mosses colonized by cyanobacteria is reported to be negatively correlated with the numbers of colonizing cyanobacteria (Rousk et al., 2013b). The moss had a higher inhibitory effect on soil bacterial growth when colonized by fewer cyanobacteria. This suggests that the cyanobacteria do not contribute to the moss' resistance toward decomposition. Nevertheless, the $\mathrm{N}$ and $\mathrm{C}$-exchange between mosses and cyanobacteria requires further study in order to identify and characterize the relationship they share.

\section{SOIL-N-CYCLING AND N-UTILIZATION PATHWAYS BY MOSSES}

Nitrogen is an essential nutrient for plants, animals, and microbes; however, the boreal forest is typically considered to be $\mathrm{N}$-limited in terms of primary productivity (Tamm, 1991). Whilst it has been assumed that this is due to the slow rate of turnover of soil organic matter and therefore the production of $\mathrm{NH}_{4}^{+}$and $\mathrm{NO}_{3}^{-}$(Read, 1991), recent evidence suggests that this is only part of the story. There is no doubt that tree needles can decompose relatively slowly in some environments after shedding (e.g., anaerobic soils); however, in mature forests, there is often only a small net accumulation of needle litter at the soil surface considering the high rate of needle shedding, suggesting that turnover is actually relatively rapid (Muukkonen, 2005). Further, much of the N entering soil occurs via fine root turnover (Yuan and Chen, 2012). However, rarely are masses of dead roots observed in the soil profile, suggesting rapid turnover possibly related to intrinsically high $\mathrm{N}$ and labile C content (Chertov et al., 2003). Part of the reason for initially thinking that slow rates of organic matter turnover were responsible for $\mathrm{N}$-limitation was the finding that concentrations of $\mathrm{NH}_{4}^{+}$and $\mathrm{NO}_{3}^{-}$were often very low in soil solution. This could be partially due to blockage of protease enzymes by high concentrations of polyphenolics in soil solution or a low $\mathrm{pH}$-induced block in nitrification (Butler and Ladd, 1971; Pajuste and Frey, 2003; Triebwasser et al., 2012). However, recent evidence suggests that it may largely reflect rapid rates of removal rather than slow rates of production (Jones and Kielland, 2002, 2012). As soil microorganisms prefer taking up the primary products of protein degradation (peptides, amino acids) this essentially prevents the direct release of $\mathrm{NH}_{4}^{+}$and thus $\mathrm{NO}_{3}^{-}$during mineralization (Farrell et al., 2013).

Due to low rates of input and rapid microbial immobilization, in most high latitude or high altitude ecosystems, inorganic $\mathrm{N}$ fluxes are found to be insufficient to cover the $\mathrm{N}$ demands of plants (e.g., Kielland, 1994). Additionally, soil solution concentrations of organic $\mathrm{N}$ concentrations are often found to be higher than inorganic $\mathrm{N}$, especially in soils with low $\mathrm{pH}$ and low inorganic N availability (Kielland, 1994, 1995; Nordin et al., 2001; Finzi and Berthrong, 2005). Thus, $\mathrm{N}$ demand of plants has to be satisfied by a combination of sources and pathways (Jones et al., 2005). Besides the uptake of mineralized, inorganic $\mathrm{N}$, plants possess the ability to take up organic $\mathrm{N}$ in the form of amino acids, urea, polyamines, and small polypeptides (Kielland, 1994; Schimel and Bennett, 2004; Krab et al., 2008; Persson and Näsholm, 2008; Hill et al., 2011) (see Figure 1). For instance,
Näsholm et al. (1998) and Persson and Näsholm (2008) showed that many boreal forest and taiga plant species have the ability to take up amino acids from soil pools. This uptake can occur indirectly via mycorrhizae or directly by the roots themselves. However, other studies showed that organic $\mathrm{N}$ represents only a minor source for plants to cover their $\mathrm{N}$ needs (Hodge et al., 2000), suggesting that the importance of this process is dependent on a range of factors including: plant, soil type, chemical form and concentration of the organic $\mathrm{N}$ source, the availability of inorganic $\mathrm{N}$, the activity of the competing microbial biomass or other plants and the time of year. Further, amino acids are removed rapidly from the soil-N pool via microbial activity, resulting in fast turnover rates of amino acids in soils (Jones and Kielland, 2002; Rousk and Jones, 2010), indicating that gross rates of N production are much greater than the typically measured net rates of N mineralization (Inselsbacher and Näsholm, 2012). It should be remembered, however, that almost all studies have investigated the unidirectional uptake of organic $\mathrm{N}$ into plants (using ${ }^{13} \mathrm{C}-{ }^{15} \mathrm{~N}$ tracers) and have largely ignored the counter efflux of amino acids and other $\mathrm{N}$ containing solutes (i.e., rhizodeposition; Jones et al., 2009). Therefore, most measured rates of uptake are therefore probably overestimates (Jones et al., 2005).

In addition to vascular plants, mosses have been found to take up amino acids from solution and directly from soil (Ayres et al., 2006; Krab et al., 2008; Hill et al., 2011). Further, it has been suggested that mosses are associated with fungi (Kauserud et al., 2008; Davey et al., 2009), which could enhance the uptake of $\mathrm{N}$ from the soil. Mosses, however, are thought to receive most of their $\mathrm{N}$ via absorption of $\mathrm{N}$ originating from atmospheric deposition, leaching and throughfall (Li and Vitt, 1997; Kotanen, 2002). While bulk atmospheric deposition is dominated by $\mathrm{NO}_{3}^{-}$ and $\mathrm{NH}_{4}^{+}$, it should be noted that canopy throughfall is often dominated by organic forms of $\mathrm{N}$ (Pelster et al., 2009). Another source of $\mathrm{N}$ for mosses is the relocation and recycling of nutrients along the moss-profile, from dead moss tissue to the growing parts at the apex (Aldous, 2002). Additionally, mosses possess an endogenous $\mathrm{N}$ supply due to their association with $\mathrm{N}_{2}$ fixing cyanobacteria (DeLuca et al., 2002; Berg et al., 2013). Thus, mosses are able to gain $\mathrm{N}$ via various sources and pathways. However, only few attempts have been made to qualitatively relate $\mathrm{N}$-acquisition processes with $\mathrm{N}$-utilization pathways in mosses. When linking $\mathrm{N}_{2}$ fixation in the feather moss Pleurozium schreberi with uptake of organic and inorganic $\mathrm{N}$ from soil by the moss, one study found no correlations (Rousk et al., 2013a). Further, the uptake of $\mathrm{N}$ from soil was very low. Thus, the moss seems to be independent of soil- $\mathrm{N}$ resources and features an internal $\mathrm{N}$-cycle that acquires $\mathrm{N}$ via absorption of atmospheric $\mathrm{N}$ and epiphytic $\mathrm{N}_{2}$ fixation, and recycling of $\mathrm{N}$ within the moss.

\section{WHERE DOES THE N GO? THE FATE OF THE FIXED $\mathrm{N}_{2}$}

Since total $\mathrm{N}$ input in boreal forests is low (Tamm, 1991; Gundale et al., 2011), moss-cyanobacteria associations likely represent a major $\mathrm{N}$ source in $\mathrm{N}$-limited ecosystems (DeLuca et al., 2002; Gundale et al., 2011). Given the great abundance of moss biomass in boreal forests (Oechel and Van Cleve, 1986) (see also Figure 2A), their $\mathrm{N}$ input could be crucial for the overall $\mathrm{N}$-cycle. However, since mosses capture and retain significant amounts 
of $\mathrm{N}$ from throughfall and deposition as well as hosting $\mathrm{N}_{2}$ fixing cyanobacteria, it has been suggested that forest ecosystems are dependent on the release of $\mathrm{N}$ from moss carpets (Weber and Van Cleve, 1984; Oechel and Van Cleve, 1986; Carleton and Read, 1991), especially in low- $\mathrm{N}$ deposition areas where $\mathrm{N}_{2}$ fixation rates in mosses are high. Thus, the biological $\mathrm{N}_{2}$ fixation in mosses is the main $\mathrm{N}$ input into the boreal forest as long as atmospheric $\mathrm{N}$ deposition is low $\left(\sim 3 \mathrm{~kg} \mathrm{~N} \mathrm{ha}^{-1} \mathrm{yr}^{-1}\right)(\mathrm{Li}$ and Vitt, 1997; Gundale et al., 2011). However, little is known about the fate of the $\mathrm{N}_{2}$ that is fixed by cyanobacteria associated with mosses. To date, there are no published reports that directly describe the transfer of biologically fixed $\mathrm{N}_{2}$ into plants (via mycorrihzae) or into the soil or to what extent that $\mathrm{N}$ is available for microorganisms and plants. Most likely, the transfer of fixed $\mathrm{N}_{2}$ to higher plants has to follow a tortuous pathway that involves decomposition of recalcitrant moss tissue (see also Hyodo et al., 2013). Assuming the fixed $\mathrm{N}_{2}$ is transferred to the soil, questions about the amount, extent and rates of the transferred $\mathrm{N}$ emerge. Several studies have shown that mosses represent a short-term ( $<1$ year) N-sink due to efficient capturing and retaining of $\mathrm{N}$ from the atmosphere (Startsev and Lieffers, 2006; Startsev et al., 2008; Friedrich et al., 2011). However, mosses can turn into a long-term ( $>1$ year) $\mathrm{N}$ source after disturbances like drying-rewetting and fire events (Carleton and Read, 1991; Wilson and Coxson, 1999), upon which $\mathrm{N}$ is released from cyanobacterial-N-enriched moss tissue and made available for $\mathrm{N}$-cycling in soils.

\section{CONCLUDING REMARKS}

Mosses colonized by diazotrophic cyanobacteria contribute significantly to the $\mathrm{N}$ pool in pristine, $\mathrm{N}$-limited forests (Figure 1). Besides that, mosses represent an iconic and important feature

\section{REFERENCES}

Ackermann, K. (2013). Nitrogen Dynamics in Boreal Forests: a Feather Moss' Perspective. Ph.D. thesis, Bangor: Bangor University, 1-162.

Ackermann, K., Zackrisson, O., Rousk, J., Jones, D. L., and DeLuca, T. H. (2012). N2 fixation in feather mosses is a sensitive indicator of $\mathrm{N}$ deposition in boreal forests. Ecosystems 15, 986-998. doi: 10.1007/s10021-012-9562-y

Adams, D. G., and Duggan, P. S. (2008). Cyanobacteria-bryophyte symbioses. J. Exp. Bot. 59, 1047-1058. doi: 10.1093/jxb/ern005

Aldous, A. R. (2002). Nitrogen retention by Sphagnum mosses: response to atmospheric nitrogen deposition. Can. J. Bot. 80, 721-731. doi: 10.1139/b02-054

Ayres, E., Van der Wal, R., Sommerkorn, M., and Bardgett, R. D. (2006). Direct uptake of soil nitrogen by mosses. Biol. Lett. 2, 286-288. doi: $10.1098 / \mathrm{rsbl} .2006 .0455$
Barron, A. R., Wurzburger, N., Bellenger, J. P., Wright, S. J., Kraepiel, A. M. L., and Hedin, L. O. (2009). Molybdenum limitation of asymbiotic nitrogen fixation in tropical forest soils. Nat. Geosci. 2, 42-45. doi: 10.1038/ngeo366

Basilier, K., and Granhall, U. (1978). Nitrogen fixation in wet minerotrophic moss communities of a subarctic mire. Oikos 31, 236-246. doi: 10.2307/3543568

Belnap, J. (2001). "Factors influencing nitrogen fixation and nitrogen release in biological soil crusts," in Biological Soil crusts: Structure, Function, and Management, eds J. Belnap and O. L. Lange (BerlinHeidelberg: Springer), 241-261. doi: 10.1007/978-3-642-56475-8_19

Bengtsson, C., Folkeson, L., and Göransson, A. (1982). Growth reduction and branching frequency in Hylocomium splendens near a foundry emitting copper and zinc. Lindbergia 8, 129-138.

Berg, A., Danielsson, Å., and Svensson, B. H. (2013). Transfer of fixed-N

in boreal forests due to their ability to influence soil hydrology and chemistry; they form extensive carpets and contribute to biomass and productivity in these forests. Further, the associated $\mathrm{N}_{2}$ fixing cyanobacteria could alleviate the pronounced $\mathrm{N}$-limitation in boreal forest ecosystems. It has been shown that $\mathrm{N}$-deposition can inhibit $\mathrm{N}_{2}$ fixation, but also, this fundamental process can recover from increased $\mathrm{N}$ loads and resume. Nitrogen fixation is strongly inhibited in dry moss, and recovery is slow, compromising the $\mathrm{N}$ input to the system, especially in dry summers. Considering future scenarios predicting changes in these factors (increasing $\mathrm{N}$ input and temperatures), the effects on the $\mathrm{N}$-cycle in boreal forest could be dramatic. Mosses uses several pathways to acquire $\mathrm{N}$, however, the most prominent is the absorption of $\mathrm{N}$ from throughfall and deposition, which could limit the $\mathrm{N}$ input to forests that are characterized by a mossdominated ground cover. Further, transfer of $\mathrm{N}$ from moss to the soil is slow and is only promoted after disturbances, indicating that the moss represents a $\mathrm{N}$ sink in the short-term $(<1$ year). However, mosses colonized by $\mathrm{N}_{2}$-fixing cyanobacteria likely act as a $\mathrm{N}$ source in the long term, releasing $\mathrm{N}$ upon disturbances like drying-rewetting and fire events. Given the moss' abundance in the boreal biome, models of ecosystem $\mathrm{N}$ and C-budgets should incorporate the nutrient fluxes within the moss layer, between the moss and its environment (atmosphere and soil) as well as the factors driving $\mathrm{N}_{2}$ fixation in moss-cyanobacteria associations. Further, more research is needed to explore and identify the relationship mosses and cyanobacteria share (see also Figure 2B).

\section{ACKNOWLEDGMENT}

This work was supported by the UK Natural Environment Research Council (Grant number: NE/I027150/1).

from N2-fixing cyanobacteria associated with the moss Sphagnum riparium results in em'nhanced growth of the moss. Plant Soil 362, 271-278. doi: 10.1007/s11104-012-1278-4

Bonan, G. B. (1991). A biophysical surface energy budget analysis of soil temperature in the boreal forests of interior Alaska. Water Res. 27, 767-781. doi: 10.1029/ 91WR00143

Butler, J. H. A., and Ladd, J. N. (1971). Importance of the molecular weight of humic and fulvic acids in determining their effects on protease activity. Soil Biol. Biochem. 3, 249-257. doi: 10.1016/0038-0717(71)90021-6

Chapin, D. M., Bliss, L. C., and Bledsoe, L. J. (1991). Environmental regulation of Nitrogen-fixation in a high arctic lowland ecosystem. Can. J. Bot. 69, 2744-2755. doi: 10.1139/ b91-345

Carleton, T. J., and Read, D. J. (1991). Ectomycorrhizas and nutrient transfer in conifer-feather moss ecosystems. Can. J. Bot. 69, 778-785. doi: 10.1139/b91-101

Chertov, O., Komarov, A., Kolstrom, M., Pitkanen, S., Strandman, H., Zudin, S., et al. (2003). Modelling the long-term dynamics of populations and communities of trees in boreal forests based on competition for light and nitrogen. For. Ecol. Manage. 176, 355-369.

Cornelissen, J. H. C., Lang, S. I., Soudzilovskaia, N. A., and During, H. J. (2007). Comparative cryptogam ecology: a review of bryophyte and lichen traits that drive biogeochemistry. Annu. Rev. Bot. 99, 987-1001. doi: 10.1093/aob/mcm030

Cox, P. A., Banack, S. A., Murch, S. J., Rasmussen, U., Tien, G., and Bidigare, R. R. (2005). Diverse taxa of cyanobacteria produce $\beta$ N-methylamino-l-alanine, a neurotoxic amino acid. Proc. Natl. Acad. Sci. U.S.A. 102, 5074-5078. doi: 10.1073/pnas.0501526102

Croisier, E., Rempt, M., and Pohnert, G. (2010). Survey of volatile 
oxylipins and their biosynthetic precursors in bryophytes. Phytochemistry 71, 574-580. doi: 10.1016/j.phytochem.2009.12.004

Davey, M. L., Nybakken, L., Kauserud, H., and Ohlson, M. (2009). Fungal biomass associated with the phyllosphere of bryophytes and vascular plants. Mycol. Res. 113, 1254-1260. doi: 10.1016/j.mycres.2009.08.001

DeLuca, T. H., and Boisvenue, C. (2012). Boreal forest soil carbon: distribution, function and modeling. Forestry 85, 161-184. doi: 10.1093/forestry/cps003

DeLuca, T. H., Zackrisson, O., Gentili, F., Sellstedt, A., and Nilsson, M. C. (2007). Ecosystem controls on nitrogen fixation in boreal feather moss communities. Oecologia 152, 121-130. doi: 10.1007/s00442-0060626-6

DeLuca, T. H., Zackrisson, O., Gundale, M. J., and Nilsson, M. C. (2008). Ecosystem feedbacks and nitrogen fixation in boreal forests. Science 320, 1181. doi: 10.1126/science. 1154836

DeLuca, T. H., Zackrisson, O., Nilsson, M. C., and Sellstedt, A. (2002). Quantifying nitrogen-fixation in feather moss carpets of boreal forests. Nature 419, 917-920. doi: 10.1038 /nature 01051

Dickson, L. G. (2000). Constraints to nitrogen fixation by cryptogamic crusts in a polar desert ecosystem, Devon Island, NWT, Canada. Arct. Antarct. Alp. Res. 32, 40-45. doi: $10.2307 / 1552408$

Eskelinen, O. (2002). Diet of the wood lemming Myopus schisticolor. Ann. Zool. Fenn. 39, 49-57.

Farrell, M., Hill, P. W., Farrar, J., DeLuca, T. H., Roberts, P., Kielland, K., et al. (2013). Oligopeptides represent a preferred source of organic N uptake: a global phenomenon? Ecosystems 16, 133-145. doi: 10.1007/s10021-012-9601-8

Finzi, A. C., and Berthrong, S. T. (2005). The uptake of amino acids by microbes and trees in three cold-temperate forests. Ecology 86, 3345-3353. doi: 10.1890/04-1460

Frank, A. B. (1877). Über die biologischen verhältnisse des thallus einiger krustenflechten. Beitr. Biol. Pflanz. 2, 123-200.

Friedrich, U., Falk, K., Bahlmann, E., Marquardt, T., Meyer, H., Niemeyer, T., et al. (2011). Fate of airborne nitrogen in heathland ecosystems: a $15 \mathrm{~N}$ tracer study. Glob. Change Biol. 17, 1549-1559. doi: 10.1111/j.13652486.2010.02322.x

Gentili, F., Nilsson, M. C., Zackrisson, O., DeLuca, T. H., and Sellstedt, A.
(2005). Physiological and molecular diversity of feather moss associative N2 -fixing cyanobacteria. J. Exp. Bot. 56, 3121-3127. doi: 10.1093/jxb/eri309

Giesler, R., Högberg, M., and Högberg, P. (1998). Soil chemistry and plants in Fennoscandian Boreal Forest as exemplified by a local gradient. Ecology 79, 119-137. doi: 10.1890/0012-9658(1998)079 [0119:SCAPIF]2.0.CO;2

Gundale, M. J., DeLuca, T. H., and Nordin, A. (2011). Bryophytes attenuate anthropogenic nitrogen inputs in boreal forests. Glob. Change Biol. 17, 2743-2753. doi: 10.1111/j.1365-2486.2011.02407.x

Gundale, M. J., Gustafsson, H., and Nilsson, M. C. (2009). The sensitivity of nitrogen fixation by a feathermoss-cyanobacteria association to litter and moisture variability in young and old boreal forest. Can. J. For. Res. 39, 2542-2549. doi 10.1139/X09-160

Gundale, M. J., Nilsson, M., Bansal, S., and Jäderlund, A. (2012a). The interactive effects of temperature and light on biological nitrogen fixation in boreal forests. New Phytol. 194, 453-463. doi: 10.1111/j.14698137.2012.04071.x

Gundale, M. J., Wardle, D. A., and Nilsson, M. C. (2012b). The effect of altered macroclimate on $\mathrm{N}$-fixation by boreal feather mosses. Biol. Lett. 8, 805-808. doi: 10.1098/rsbl.2012. 0429

Hawes, I., Howard-Williams, C., and Vincent, W. F. (1992). Desiccation and recovery of Antarctic cyanobacterial mats. Polar Biol. 12, 587-594. doi: 10.1007/ BF00236981

Hill, P. W., Farrar, J., Roberts, P., Farrell, M., Grant, H., Newsham, K. K., et al. (2011). Vascular plant success in a warming Anarctic may be due to efficient nitrogen acquisition. Nat. Clim. Change 1, 50-53. doi: 10.1038/nclimate1060

Hobbie, S. E. (1996). Temperature and plant species control over litter decomposition in alaskan tundra. Ecol. Monogr. 66, 503-522. doi: $10.2307 / 2963492$

Hodge, A., Stewart, J., Robinson, D., Griffiths, B. S., and Fitter, A. H. (2000). Spatial and physical heterogeneity of $\mathrm{N}$ supply from soil does not influence $\mathrm{N}$ capture by two grass species. Funct. Ecol. 14, 575-584. doi: $10.1046 / j .1365-2435.2000 . t 01-$ 1-00470.x

Houlton, B. Z., Wang, Y. P., Vitousek, P. M., and Field, C. B. (2008). A unifying framework for dinitrogen fixation in the terrestrial biosphere. Nature 454, 327-330. doi: 10.1038/nature07028

Hyodo, F., Kusaka, S., Wardle, D. A., and Nilsson, M. C. (2013). Changes in stable nitrogen and carbon isotope ratios of plants and soil across a boreal forest fire chronosequence. Plant Soil 364, 315-323. doi: 10.1007/s11104-0121339-8

Ininbergs, K., Bay, G., Rasmussen, U., Wardle, D. A., and Nilsson, M. C. (2011). Composition and diversity of nifH genes of nitrogenfixing cyanobacteria associated with boreal forest feather mosses. New Phytol. 192, 507-517. doi: 10.1111/j.1469-8137.2011.03809.x

Inselsbacher, E., and Näsholm, T. (2012). The below-ground perspective of forest plants: soil provides mainly organic nitrogen for plants and mycorrhizal fungi. New Phytol. 195, 329-334. doi: 10.1111/j.1469-8137.2012.04169.x

IPCC. (2007). "In climate change 2007: the physical science basis," in Contribution of Working Group I to the Fourth Assessment Report of the Intergovernmental Panel on Climate Change, eds S. Solomon, D. Qin, M. Manning, Z. Chen, M. Marquis, K. B. Averyt et al. (Cambridge, UK; New York, NY: Cambridge University Press).

Jackson, B. G., Martin, P., Nilsson, M. C., and Wardle, D. A. (2011). Response of feather moss associated N2 fixation and litter decomposition to variations in simulated rainfall intensity and frequency. Oikos 120, 570-581. doi: 10.1111/j.16000706.2010.18641.x

Jean, M. E., Cassar, N., Setzer, C., and Bellenger, J. P. (2012). Shortterm N2 fixation kinetics in a mossassociated cyanobacteria. Environ. Sci. Technol. 46, 8667-8671. doi: 10.1021/es3018539

Johansson, O., Olofsson, J., Giesler, R., and Plamqvist, K. (2011). Lichen responses to nitrogen and phosphorus additions can be explained by the different symbiont responses. New Phytol. 191, 795-805. doi: 10.1111/j.1469-8137.2011.03739.x

Jones, D. L., Healey, J. R., Willett, V. B., Farrar, J. F., and Hodge, A. (2005). Dissolved organic nitrogen uptake by plants-an important N uptake pathway? Soil Biol. Biochem. 37, 413-423. doi: 10.1016/j.soilbio.2004.08.008

Jones, D. L., and Kielland, K. (2002). Soil amino acid turnover dominates the nitrogen flux in permafrostdominated taiga forest soils. Soil Biol. Biochem. 34, 209-219. doi: 10.1016/S0038-0717(01)00175-4
Jones, D. L., and Kielland, K. (2012). Amino acid, peptide and protein mineralization dynamics in a taiga forest soil. Soil Biol. Biochem. 55, 60-69. doi: 10.1016/j.soilbio.2012.06.005

Jones, D. L., Nguyen, C., and Finlay, R. D. (2009). Carbon flow in the rhizosphere: carbon trading at the soil-root interface. Plant Soil 321, 5-33. doi: 10.1007/s11104-0099925-0

Kaasalainen, U., Fewer, D. P., Jokela, J., Wahlsten, M., Sivonen, K., and Rikkinen, J. (2012). Cyanobacteria produce a high variety of hepatotoxic peptide in lichen symbiosis. Proc. Natl. Acad. Sci. U.S.A. 109, 5886-5891. doi: 10.1073/pnas.1200279109

Kaasalainen, U., Jokela, J., Fewer, D. P., Sivonen, K., and Rikkinen, J. (2009). Microcystin production in the tripartite cyanolichen Peltigera leucophlebia. Mol. Plant Microbe Interact. 22, 695-702. doi: 10.1094/MPMI-22-6-0695

Kaplan-Levy, R. N., Hadas, O., Summers, M. L., Rücker, J., and Sukenik, A. (2010). "Akinetes: dormant cells of cyanobacteria," in Dormancy and Resistance in Harsh Environments, Topics in Current Genetics. Vol. 21, eds E. Lubzens, J. Cerda, and M. Clark (Berlin Heidelberg: Springer), 5-27.

Kauserud, H., Mathiesen, C., and Ohlson, M. (2008). High diversity of fungi associated with living parts of boreal forest bryophytes. Botany 86, 1326-1333. doi: 10.1139/B08-102

Keeney, D. R. (1980). Prediction of soil nitrogen availability in forest ecosystems: a literature review. For Sci. 26, 159-171.

Kielland, K. (1994). Amino acid absorption by arctic plants: implications for plant nutrition and nitrogen cycling. Ecology 75, 2373-2383. doi: 10.2307/1940891

Kielland, K. (1995). Landscape patterns of free amino acids in arctic tundra soils. Biogeochem 31, 85-98. doi: 10.1007/BF00000940

Kotanen, P. M. (2002). Fates of added nitrogen in freshwater arctic wetlands grazed by snow geese: the role of mosses. Arct. Ant. Alp. Res. 34, 219-225. doi: 10.2307/1552474

Krab, E. J., Cornelissen, J. H. C. Lang, S. I., and van Logtestijn, R. S. P. (2008). Amino acid uptake among wide-ranging moss species may contribute to their strong position in higher-latitude ecosystems. Plant Soil 304, 199-208. doi: 10.1007/s11104-008-9540-5

Lang, S. I., Cornelissen, J. H. C., Klahn, T., Van Logtesijn, R. S. P., 
Broekman, R., Schweikert, W., et al. (2009). An experimental comparison of chemical traits and litter decomposition rates in a diverse range of subarctic bryophyte, lichen and vascular plant species. J. Ecol. 97, 886-900. doi: 10.1111/j.13652745.2009.01538.x

Leppänen, S. M., Salemaa, M., Smolander, A., Mäkipää, R., and Tiirola, M. (2013). Nitrogen fixation and methanotrophy in forest mosses along a $\mathrm{N}$ deposition gradient. Environ. Exp. Bot. doi: 10.1016/j.envexpbot.2012.12.006

Li, Y., and Vitt, D. H. (1997). Patterns of retention and utilization of aerially deposited nitrogen in boreal peatlands. Écoscience 4, 106-116.

Lindo, Z., and Gonzalez, A. (2010). The bryosphere: an integral and influential component of the earth's biosphere. Ecosystems 13, 612-627. doi: 10.1007/s10021010-9336-3

Longton, R. E. (1988). Biology of Polar Bryophytes and Lichens. Cambridge: Cambridge University Press. doi: 10.1017/CBO9780511565212

Martin, C. E., and Adamson, V. J. (2001). Photosynthetic capacity of mosses relative to vascular plants. J. Bryol. 23, 319-323.

Matsui, K. (2006). Green leaf volatiles: hydroperoxide lyase pathway of oxylipin metabolism. Curr. Opin. Plant Biol. 9, 274-280. doi: 10.1016/j.pbi.2006.03.002

Meeks, J. C. (2009). Physiological adaptations in nitrogen-fixing Nostoc-plant symbiotic associations. Microbiol. Monogr. 8, 181-205. doi: 10.1007/7171_ 2007_101

Meeks, J. C., and Elhai, J. (2002). Regulation of cellular differentiation in filamentous cyanobacteria in free-living and plant associated symbiotic growth states. Microbiol. Mol. Biol. Rev. 65, 94-121. doi: 10.1128/MMBR.66.1.94-121.2002

Muukkonen, P. (2005). Needle biomass turnover rates of Scots pine (Pinus sylvestris L.) derived from the needle-shed dynamics. Trees 19, 273-279. doi: 10.1007/s00468-004-0381-4

Näsholm, T., Ekblad, A., Nordin, A., Giesler, R., Högberg, M., and Högberg, P. (1998). Boreal forest plants take up organic nitrogen. Nature 392, 914-916. doi: $10.1038 / 31921$

Nordin, A., Högberg, P., and Näsholm, T. (2001). Soil nitrogen form and plant nitrogen uptake along a boreal forest productivity gradient. Oecologia 129, 125-132. doi: $10.1007 / \mathrm{s} 004420100698$
Nordin, A., Strengbom, J., and Ericson, L. (2006). Responses to ammonium and nitrate additions by boreal plants and their natural enemies. Environ. Pollut. 141, 167-174. doi: 10.1016/j.envpol.2005.08.017

Oechel, W. C., and Van Cleve, K. (1986). "The role of bryophytes in nutrient cycling in the taiga," in Forest Ecosystems in the Alaskan Taiga: A Synthesis of Structure and Function, eds K. Van Cleve, F. S. Chapin, III, P. W. Flanagan, L. A. Viereck, and C. T. Dyrness (New York, NY: Springer), 121-137.

Pajuste, K., and Frey, J. (2003). Nitrogen mineralisation in podzol soils under boreal Scots pine and Norway spruce stands. Plant Soil 257, 237-247. doi: 10.1023/A:1026222831694

Pelster, D. E., Kolka, R. K., and Prepas, E. E. (2009). Overstory vegetation influence nitrogen and dissolved organic carbon flux from the atmosphere to the forest floor: Boreal Plain, Canada. For. Ecol. Manage. 259, 210-219. doi: 10.1016/j.foreco.2009.10.017

Persson, J., and Näsholm, T. (2008). Amino acid uptake: a widespread ability among boreal forest plants. Ecol. Lett. 4, 434-438. doi: 10.1046/j.1461-0248.2001.00260.x

Phil-Karlsson, G., Akselsson, C., Hellsten, S., Karlsson, P. E., and Malm, G. (2009). Vol. IVL rapport B 1851. IVL. Svenska Miljöinstitutet. Göteborg.

Prescott, C. E., Taylor, B. R., Parsons, W. F. J., Durall, D. M., and Parkinson, D. (1993). Nutrient release from decomposing litter in Rocky Mountain coniferous forests: influence of nutrient availability. Can. J. For. Res. 23, 1576-1586. doi: 10.1139/x93-198

Prins, H. H. T. (1982). Why are mosses eaten in cold environments only? Oikos 38, 374-380. doi: $10.2307 / 3544680$

Proctor, M. C. F. (2001). Patterns of desiccation tolerance and recovery in bryophytes. Plant Growth Regul. 35, 147-156. doi: 10.1023/A:1014429720821

Proctor, M. C. F., Oliver, M. J., Wood, A. J., Alpert, P., Stark, L. R., Cleavitt, N. L., et al. (2007). Desiccation tolerance in bryophytes: a review. Bryologist 110, 595-621. doi: 10.1639/0007-2745 (2007) 110[595:DIBAR]2.0.CO;2

Rai, A. N., Bergmann, B., and Rasmussen, U. (2002). Cyanobacteria in Symbiosis. Dordrecht: Kluwer Academic.

Rai, A. N., Söderbäck, E., and Bergman, B. (2000). Cyanobacterium-plant symbioses. New Phytol. 147, 449-481. doi: 10.1046/j.1469-8137. 2000.00720.x

Read, D. J. (1991). Mycorrhizas in ecosystems. Experientia 47, 376-391. doi: 10.1007/BF01972080

Reed, S. C., Cleveland, C. C., and Townsend, A. R. (2011). Functional ecology of free-living nitrogen fixation: a contemporary perspective. Annu. Rev. Ecol. Evol. Syst. 42, 489-512. doi: 10.1146/annurevecolsys-102710-145034

Reed, S. C., Cleveland, C. C., and Townsend, A. R. (2013). Relationships among phosphorus, molybdenum and free-living nitrogen fixation in tropical rain forests: results from observational and experimental analyses. Biogeochem doi: 10.1007/s10533-013-9835-9833

Rousk, J., and Jones, D. L. (2010). Loss of low molecular weight dissolved organic carbon (DOC) and nitrogen (DON) in $\mathrm{H} 2 \mathrm{O}$ and $0.5 \mathrm{M} \mathrm{K} 2 \mathrm{SO} 4$ soil extracts. Soil Biol. Biochem. 42, 2331-2335. doi: 10.1016/j.soilbio. 2010.08.017

Rousk, K., Rousk, J., Jones, D. L., Zackrisson, O., and DeLuca, T. H. (2013a). Feather moss nitrogen acquisition across natural fertility gradients in boreal forests. Soil Biol. Biochem. 61, 86-95.

Rousk, K., DeLuca, T. H., and Rousk, J. (2013b). The cyanobacterial role in the resistance of feather mosses to decomposition - toward a new hypothesis. PLOS ONE 8:e62058. doi: 10.1371/journal. pone. 0062058

Scherer, S., and Zhong, Z. P. (1991). Desiccation independence of terrestrial Nostoc commune ecotypes (cyanobacteria). Microbial. Ecol. 22, 271-283. doi: 10.1007/ BF02540229

Schimel, J. P., and Bennett, J. (2004). Nitrogen mineralization: challenges of a changing paradigm. Ecology 85, 591-602. doi: 10.1890/ 03-8002

Scott, G. D. (1960). Studies of the lichen symbiosis. I. The relationship between nutrition and moisture content in the maintenance of the symbiotic state. New Phytol. 59, 374-381. doi: 10.1111/j.14698137.1960.tb06232.x

Scott, N. A., and Binkley, D. (1997). Foliage litter quality and annual net $\mathrm{N}$ mineralization: comparison across North American forest sites. Oecologia 111, 151-159. doi: $10.1007 / \mathrm{s} 004420050219$

Sivonen, K. (2009). "Cyanobacterial toxins," in The Encyclopedia of Microbiology, 3rd Edn., eds M.
Schaechter (Oxford: Academic), 290-307.

Smith, V. R. (1984). Effects of abiotic factors on acetylene reduction by cyanobacteria epiphytic on moss at a subantarctic island. Appl. Environ. Microbiol. 48, 594-600.

Solga, A., Burkhardt, J., Zechmeister, H. G., and Frahm, J. P. (2005) Nitrogen content, $15 \mathrm{~N}$ natural abundance and biomass of the two pleurocarpous mosses Pleurozium schreberi (Brid.) Mitt. and Scleropodium purum (Hedw.) Limpr. in relation to atmospheric nitrogen deposition. Environ. Pollut. 134, 465-473. doi 10.1016/j.envpol.2004.09.008

Sorensen, P. L., Jonasson, S. E., and Michelsen, A. (2006). Nitrogen fixation, denitrification, and ecosystem nitrogen pools in relation to vegetation development in the Subarctic. Arct. Ant. Alp. Res. 38, 263-272. doi: 10.1657/ 1523-0430(2006)38[263:NFDAEN] 2.0.CO; 2

Sorensen, P. L., Lett, S., and Michelsen, A. (2012). Moss-specific changes in nitrogen fixation following two decades of warming, shading, and fertilizer addition. Plant Ecol. 213, 695-706. doi: 10.1007/s11258-0120034-4

Sorensen, P. L., and Michelsen, A. (2011). Long-term warming and litter addition affects nitrogen fixation in a subarctic heath. Glob. Change Biol. 17, 528-537. doi 10.1111/j.1365-2486.2010.02234.x

Startsev, N. A., and Lieffers, V. J. (2006). Dynamic of mineral nitrogen release from feathermosses after dehydration or handling stress. Bryologist 109, 551-559. doi: 10.1639/00072745(2006)109[551:DOMNRF]2.0. $\mathrm{CO} ; 2$

Startsev, N. A., Lieffers, V. J., Landhäuser, S. M., and VelazquezMartinez, A. (2008). N-transfer through aspen litter and feather moss layers after fertilization with ammonium nitrate and urea. Plant Soil 311, 51-59. doi: 10.1007/s11104-008-9657-6

Startsev, N. A., Lieffers, V. J., and McNabb, D. H. (2007). Effects of feathermoss removal, thinning and fertilization in lodgepole pine growth, soil microclimate and stand nitrogen dynamics. For Ecol. Manage. 240, 79-86. doi: 10.1016/j.foreco.2006.12.010

Steinberg, N. A., and Meeks, J. C. (1991). Photosynthetic CO2 fixation and ribulose bisphosphate carboxylase/oxygenase activity of Nostoc sp. strain UCD (7801). 
in symbiotic association with Anthoceros punctatus. J. Bacteriol. 171, 6227-6233.

Storeheier, P. V., Mathiesen, S., Tyler, N., and Olsen, M. (2002). Nutritive value of terricolous lichens for reindeer in winter. Lichenologist 34, 247-257. doi: 10.1006/lich.2002.0394

Street, L. E., Subke, J. A., Sommerkorn, M., Sloan, V., Ducrotoy, H., Phoenix, G. K., et al. (2013). The role of mosses in carbon uptake and partitioning in arctic vegetation. New Phyt. doi: 10.1111/ nph. 12285

Sveinbjörnsson, B., and Oechel, W. C. (1992). "Controls of growth and productivity of bryophytes: environmental limitations under current and anticipated condition," in Bryophytes and Lichens In A Changing Environment eds J. W. Bates and A. M. Farmer (Oxford, UK: Clarendon Press), 77-102.

Tamm, C. O. (1991). Nitrogen in Terrestrial Ecosystems. Berlin: Springer. doi: 10.1007/978-3-64275168-4

Triebwasser, D. J., Tharayil, N., Preston, C. M., and Gerard, P. D. (2012). The susceptibility of soil enzymes to inhibition by leaf litter tannins is dependent on the tannin chemistry, enzyme class and vegetation history. New Phytol. 196, 1122-1132. doi: 10.1111/j.1469-8137.2012.04346.x

Turetsky, M. R. (2003). The role of bryophytes in carbon and nitrogen cycling. Bryologist 106, 395-109. doi: $10.1639 / 05$

Tyler, G. (1990). Bryophytes and heavy metals: a literature review. Bot. J. Linn. Soc. 104, 231-253. doi: 10.1111/j.10958339.1990.tb02220.x

Van Cleve, K., Oliver, L. K., Schlentner, P., Viereck, L. A., and Dyrness, C. T. (1983). Productivity and nutrient cycling in taiga forest ecosystems. Can. J. For. Res. 13, 747-766. doi: 10.1139/x83-105

Vitousek, P., and Hobbie, S. (2000). Heterotrophic nitrogen fixation in decomposing litter: patterns, mechanisms, and models. Ecology 75, 418-429. doi: 10.2307/ 1939545

Vitousek, P. M., Mooney, H. A., Lubchenco, J., and Melilo, J. M. (1997). Human domination of earth's ecosystems. Science 277, 494-499. doi: 10.1126/science.277.5325.494

Weber, M. G., and Van Cleve, K. (1984). Nitrogen transformation in feather moss and forest floor layers of interior Alaska black spruce ecosystems. Can. J. For. Res. 14, 278-290. doi: 10.1139/x84-053

Wilson, J. A., and Coxson, D. S. (1999). Carbon flux in a subalpine spruce-fir forest: pulse release from Hylocomium splendens feather-moss mats. Can. J. Bot. 77, 564-569. doi: 10.1139/cjb-774-564

Wurzburger, N., Bellenger, J. P., Kraepiel, A. M. L., and Hedin, L. O. (2012). Molybdenum and phosphorus interact to constrain asymbiotic nitrogen fixation in tropical forests. PLOS ONE 7:e33710. doi: $\quad 10.1371 /$ journal.pone. 0033710

Yuan, Z. Y., and Chen, H. Y. H (2012). Fine root dynamics with stand development in the boreal forest. Func. Ecol. 26, 991-998. doi: $\quad 10.1111 /$ j.1365-2435.2012 02007.x

Zackrisson, O., DeLuca, T. H., Gentili, F., Sellstedt, A., and Jäderlund, A. (2009). Nitrogen fixation in mixed Hylocomium splendens moss communities. Oecologia 160, 309-319. doi: 10.1007/s00442-009-1299-8

Zackrisson, O., DeLuca, T. H., Nilsson, M. C., Sellstedt, A., and Berglund, L. M. (2004). Nitrogen fixation inreases with successional age in boreal forests. Ecology 85, 3327-3334. doi: 10.1890/04-0461

Conflict of Interest Statement: The authors declare that the research was conducted in the absence of any commercial or financial relationships that could be construed as a potential conflict of interest.

Received: 12 April 2013; accepted: 28 May 2013; published online: 17 June 2013.

Citation: Rousk K, Jones DL and DeLuca TH (2013) Moss-cyanobacteria associations as biogenic sources of nitrogen in boreal forest ecosystems. Front. Microbiol. 4:150. doi: 10.3389/fmicb. 2013.00150

This article was submitted to Frontiers in Terrestrial Microbiology, a specialty of Frontiers in Microbiology.

Copyright (c) 2013 Rousk, Jones and DeLuca. This is an open-access article distributed under the terms of the Creative Commons Attribution License, which permits use, distribution and reproduction in other forums, provided the original authors and source are credited and subject to any copyright notices concerning any third-party graphics etc. 